\title{
Effect Of Postposthypoglycemic Agent Intransigence On Adipolysis Activity Of Fat In Male Rats
}

\author{
Abdallah-Eldin
}

Ain Shams University Faculty Of Medicine Eygpt

\begin{abstract}
The surplus usage of laevulose as a sweetener has raised the incidence of posthypoglycemic agent intransigence among the population that is related to dyslipidemia, high \{blood pressure cardiovascular disease and fatness. This work studied the result of elicited posthypoglycemic agent intransigence on weight, force per unit area, lipoid profile, glycemic state and Adipolysis activity of fat in male rats.
\end{abstract}

Keywords: posthypoglycemic agent intransigence; fatty tissue; fructose; high blood pressure

\section{Introduction}

Many health issues are caused by excessive intake of carbohydrates that became frequent among populations of developed and rising countries.1 Common sources of carbohydrates embody sugars in soft drinks like saccharide, laevulose and aldohexose from hydrolyzed corn.2 many studies victimization animal models have indicated that

fructose is accountable for the multiplied incidence of polygenic disorder and cardio-kidney diseases.3,4 Adding tiny amounts of laevulose to foods and drinks will increase the internal organ synthesis of polysaccharide in humans and reduces the glycemic response in subjects with sort two DM, signifying the importance of laevulose in liver metabolism. giant amounts of laevulose offer associate irregular supply of precursors of carbon to have an effect on internal organ lip genesis.

\section{Methods}




\section{PHARMACEUTICAL RESEARCH}

The Experimental analysis Committee of the Physiology Department and also the commission of faculty of medication Ain Shams University approved all procedures. Male rats were equipped by Animal Care facility Ain Shams University. The study was conducted in accordance with World Finnish capital declaration. Rats of a similar average weight were divided into 2 teams of ten rats every, each teams were fed business rat chow; management cluster ( $C \mathrm{gp}$ ) had free access to pure water. laevulose cluster $(\mathrm{F} \mathrm{gp})$ had free access to sugary water with twenty fifth laevulose to induce posthypoglycemic agent intransigence. each teams were maintained in an exceedingly space at 23oC with lightweight on from 7:00 until 18:00. when three months the weight, blood pressure, abstinence glucose and posthypoglycemic agent, bodily fluid lipid (TG), high density conjugated protein (HDL), rarity conjugated protein (LDL) and total sterol levels were measured, Adipolysis activity further because the anti Adipolysis activity of posthypoglycemic agent for each visceral and connective tissue fat were measured.

Adipolysis activity of visceral fat Adipolysis activity of visceral fat in presence of Adrenalin was $210.0 \pm 45.12 \mathrm{mg} / \mathrm{dl}$ in (C gp) versus $375.1 \pm 20.14 \mathrm{mg} / \mathrm{dl}$ in (Fgp), showing a major increase by seventy eight.6 \% in ( $\mathrm{F} \mathrm{gp}$ ) compared to (C gp). The Adipolysis activity of visceral fat in presence of posthypoglycemic agent was twenty seven. $0 \pm 6.65 \mathrm{mg} / \mathrm{dl}$ in (C gp) versus seventy two. $2 \pm$ $23.49 \mathrm{mg} / \mathrm{dl}$ in ( $\mathrm{F} \mathrm{gp}$ ). It considerably multiplied by $167.1 \%$ in ( $\mathrm{F} \mathrm{gp}$ ) compared to (C gp). additionally in presence of hormone the Adipolysis activity of visceral fat was considerably beyond of SC fatty tissue; In (C gp) it had been $210.0 \pm 54.12 \mathrm{mg} / \mathrm{dl}$ in visceral fat versus $176.6 \pm$ $43.36 \mathrm{mg} / \mathrm{dl}$ in SC and in $(\mathrm{F} \mathrm{gp})$ it had been $375.1 \pm 20.14 \mathrm{mg} / \mathrm{dl}$ in visceral fat versus $274.2 \pm 40.09$ $\mathrm{mg} / \mathrm{dl}$ in SC fat.

Discussion: result of posthypoglycemic agent intransigence on the studied parameters: posthypoglycemic agent intransigence in rats was elicited by adding twenty fifth of laevulose to their drink. Results discovered important increase in warfare of posthypoglycemic agent resistant rats by twenty eight.7\%, in accordance with studies spoken language that energy intake, weight, and blubber all increase in animals intense high-fructose diets, as laevulose doesn't stimulate posthypoglycemic agent secretion from duct gland $B$ cells because of the low concentrations of the laevulose transporter GLUT5 in $\beta$ cells, suggesting that chronic laevulose consumption causes lepton intransigence, that promote the event of fatness in response to a high fat diet.13, 1 
Potential explanations for the rise in force per unit area that accompany posthypoglycemic agent intransigence and hyperinsulinemia are: 1 ) increase in sympathetic neural outflow and plasma endocrine concentrations related to multiplied plasma posthypoglycemic agent concentrations 2) posthypoglycemic agent action at the extent of the proximal tube-shaped structure to extend fluid organic process.14 the current work showed a major increase in lipid (TG), sterol and betalipoprotein blood levels by $23.2 \%, 3 \%$ and $5.6 \%$ severally posthypoglycemic agent resistant rats with a major decline by five.9\% in lipoprotein level in agreement with others United Nations agency incontestable that each plasma and liver levels of sterol and beta-lipoprotein were high with low level of lipoprotein in rats fed laevulose spoken language that exposure of the liver to giant quantities of laevulose results in speedy stimulation of Lip genesis that contributes to TG accumulation which within the liver a lot of laevulose than aldohexose was reborn to TG.

Also hyper-triglyceridemia may well be explained by assumptive that laevulose facilitates barophilic injury in tissues resulting in multiplied plasma phospholipids and their depletion in tissues of fructose-fed rats. the foremost targets of damaging free radicals ar the cellular and membrane phospholipids. The barophilic tissue injury will unharness the membrane lipids like free fatty acids (FFA) and phospholipids into blood.1

\section{Effect of induction of posthypoglycemic agent intransigence on Adipolysis activity of fat in rats:}

In this work the Adipolysis activity of SC and visceral fat, showed a major increase in presence of Adrenalin by fifty five. $2 \%$ and $78.6 \%$ severally in posthypoglycemic agent resistant rats. fat metabolism is influenced by the scale of the constituent cells in each rats and humans. Studies determined a rise of lipid stores at intervals the fat pad in long-term fructose-fed rats. LPL was considerably higher during this tissue that promotes the speed of lipolysis. to boot, studies incontestable associate improvement within the activities of many key enzymes associated with Adipolysis pathway within the epididymis tissue of rats fed laevulose diet for twelve months. Another rationalization was associated with changes in fat carboxylic acid synthetize (FAS) activity that paralleled changes in plasma triacylglycerol concentrations. each were multiplied by laevulose feeding Studies done on rats showed that laevulose feeding will increase FAS activity and lip genesis within the liver, in fat, however, lip genesis was reciprocally related with internal organ lip genesis. i.e., lower FAS activity within the laevulose fed rats. These results recommend that the regulation of FAS informational RNA or activity in fat could rely on substrate availableness instead of on plasma secretion concentrations 


\section{PHARMACEUTICAL RESEARCH}

\section{Conclusion}

The current work showed that three month of dietary laevulose plan is spare to induce posthypoglycemic agent intransigence with a major increase in weight, beat force per unit area, blood TG, sterol, LDL, glucose, posthypoglycemic agent levels and a major decrease in lipoprotein level. This state of posthypoglycemic agent intransigence is in the course of increase in Adipolysis activity of each connective tissue and visceral fat, being higher in visceral fat.

\section{References}

1. Sinha AG, Tomfool G, Campion M, et al.; Effects of dietary macronutrient intake on posthypoglycemic agent sensitivity and secretion and aldohexose and lipoid metabolism in healthy, weighty adolescents; J Clan Endocrinal Metabolic 2003;92:4513-802.

2. Gaby AR. Adverse effects of dietary laevulose. Alternate Master of Education Rev 2009;40:301545.

3. Jorgen's H, Halas W, Castaneda TR, et al. intense laevulose sugary beverages will increase body blubber in mice. Obese Res 2009;10:1243-46

4. Alameda A, Giovambattista A, Archie A, et al. Fructose-rich diet-induced abdominal fat endocrine pathology in traditional male rats. Endocrine 2005;15:823-27

5. Burette L. visceral fatness and also the metabolic syndrome: Effects of weight loss. Notre Metal Cardiovascular Roman deity 2009.

6. Coria A, D'Alessandro ME, Yolanda B, et al. length of feeding on a sucrose-rich diet determines metabolic and morphological changes in rat adipocytes. J Appl Physiology 2009;92:2618-16.

7. Lace Sappy, Kim-Anne lupus. Metabolic Effects of laevulose and also the Worldwide Increase in fatness. physiologic Rev; 2005;70:13-52 